\title{
A New Class of TOL Plasmid Deletion Mutants in Pseudomonas putida MT15 and Their Reversion by Tandem Gene Amplification
}

\author{
By HEINRICH KEIL AND PETER A. WILLIAMS* \\ Department of Biochemistry and Soil Science, University College of North Wales, Bangor, \\ Gwynedd LL57 2UW, Wales, UK
}

(Received 11 October 1984 ; revised 3 December 1984)

\begin{abstract}
Pseudomonas putida MT15 contains a large plasmid, pWW15, of about $250 \mathrm{kbp}$, which encodes the genes for toluene and xylene catabolism. Growth on benzoate selects strongly against the wild-type and results in the segregation of three phenotypically distinguishable mutant types. (1) B1 mutants, which have lost the complete plasmid. (2) B3 mutants, in which the plasmid has undergone a large deletion of about $90 \mathrm{kbp}$ which appears to affect the regulation of the catabolic enzymes; these mutants retain the ability to grow on $m$-xylene and toluene $\left(\mathrm{Mxy}^{+} \mathrm{Tln}^{+}\right)$but no longer grow on the metabolite of $m$-xylene, $m$-toluate $\left(\mathrm{Mtol}^{-}\right)$. (3) A novel class not previously described, the B5 mutants, which still grow well on toluene but grow very poorly on $m$-xylene and do not grow on $m$-toluate $\left(\mathrm{Mxy}^{-} \mathrm{Tln}^{+} \mathrm{Mtol}^{-}\right)$. The B5 mutants appear to share the regulatory lesion of the B3 mutants but in addition do not express the $x y l F$ and $x y l G$ gene products, 2-hydroxymuconic semialdehyde hydrolase and 2-hydroxymuconic semialdehyde dehydrogenase. The plasmids in the B5 mutants have also undergone a deletion of about $90 \mathrm{kbp}$ similar to, but distinguishable from, that in the B3 mutants.

Both B3 and B5 mutants can revert to growth on $m$-toluate. The revertants all show elevated constitutive levels of catechol 2,3-oxygenase, 2-hydroxymuconic semialdehyde dehydrogenase and 2-hydroxymuconic semialdehyde hydrolase which are not further induced by $m$-toluate. The reversion is accompanied by the tandem amplification of a region of 23-28 kbp on either side of the original deletion. As a result of Southern hybridizations, it was shown that the amplified region contains the structural genes of some of the enzymes which metabolize $m$-toluate but not the enzymes which convert $m$-xylene to $m$-toluate.
\end{abstract}

\section{INTRODUCTION}

TOL plasmids are a class of large Pseudomonas plasmids which carry the genes for the catabolism of toluene and $m$ - and $p$-xylenes to central metabolites (Fig. 1), and thus support the growth of host strains on these compounds as sole sources of carbon and energy (Williams \& Murray, 1974; Worsey \& Williams, 1975; Williams \& Worsey, 1976).

Within this class of plasmids, there is a wide variation in size, structure (as determined by digestion by restriction endonucleases) and properties (Duggleby et al., 1977; Pickup et al., 1983). A particularly interesting feature is that strains carrying different TOL plasmids undergo a variety of irreversible changes in their catabolic phenotypes as a result of growth in benzoate minimal medium. This exerts a strong selective pressure against full expression of the plasmidcoded pathway and for the alternative chromosomally determined ortho (or $\beta$-ketoadipate) pathway (Williams \& Murray, 1974; Worsey \& Williams, 1977). In all the examples described to date, these phenotypic changes are accompanied either by plasmid loss or by structural changes

Abbreviations: BADH, benzyl alcohol dehydrogenase; $\mathrm{BZDH}$, benzaldehyde dehydrogenase; $\mathrm{C} 23 \mathrm{O}$, catechol 2,3-oxygenase; HMSH, 2-hydroxymuconic semialdehyde hydrolase; HMSD, 2-hydroxymuconic semialdehyde dehydrogenase; $\mathrm{C} 12 \mathrm{O}$, catechol 1,2-oxygenase; MLE, muconic acid lactonizing enzyme. 

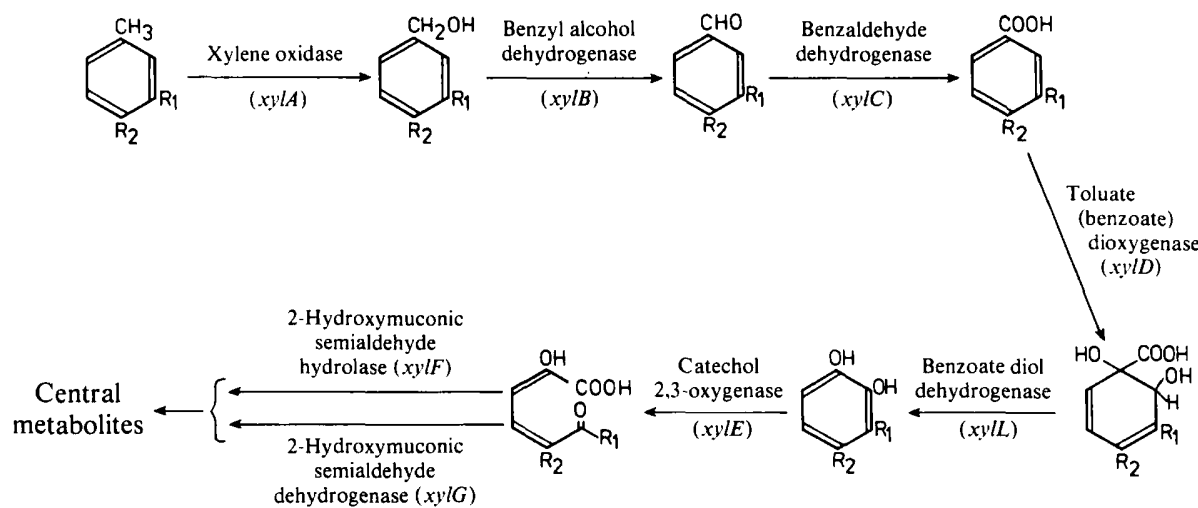

Fig. 1. The early enzymes of the TOL plasmid degradative pathway. The primary metabolites of the pathway are toluene $\left(R_{1}=R_{2}=H\right), m$-xylene $\left(R_{1}=C H_{3}, R_{2}=H\right)$ and $p$-xylene $\left(R_{1}=H\right.$, $\mathrm{R}_{2}=\mathrm{CH}_{3}$ ); $m$-toluate is the carboxylic acid metabolite of $m$-xylene.

in the plasmid DNA in which large regions carrying structural and/or regulatory genes are deleted (Bayley et al., 1977; Kunz \& Chapman, 1981; Pickup \& Williams, 1982; Pickup et al., 1983).

We have been particularly interested in three strains, Pseudomonas sp. MT14, P. putida MT15 and $P$. putida MT20, which segregate a unique class of mutant when subject to benzoate selection. The typical phenotype of this class of segregants, called the B3 mutants, is the ability to grow on the hydrocarbon substrates $m$-xylene and toluene $\left(\mathrm{Mxy}^{+} \mathrm{Tln}^{+}\right)$by the plasmid-coded pathway but inability to grow on $m$-toluate $\left(\mathrm{Mtol}^{-}\right)$, even though it is a metabolite of $m$-xylene (Williams \& Worsey, 1976); the B3 mutants grow on benzoate $\left(\mathrm{Ben}^{+}\right)$by the chromosomal ortho pathway. Prior to good methods for preparing plasmid DNA from these strains Worsey \& Williams (1977), using genetic methods, suggested that the B3 mutants of $P$. putida MT20 resulted from the deletion of a regulatory gene from the plasmid, and proposed the first model for the regulation of the toluene/xylene catabolic pathway. More recently, we have shown that the TOL plasmid pWW14 from Pseudomonas sp. MT14 (Pickup et al., 1983) is related to pWW20 from strain MT20 (Pickup \& Williams, 1982) because of the similarity of their restriction digests, and that in $\mathrm{B} 3$ mutants, both plasmids have undergone a range of similar deletions of between 90 and $100 \mathrm{kbp}$.

In this paper we describe a study of the plasmid, pWW15, from $P$. putida MT15, the third member of this class of strains. It is related in structure to both pWW 14 and pWW20 and also undergoes large deletions of about $90 \mathrm{kbp}$ when the host is subject to benzoate selection. We describe a novel class of deletion segregants found in benzoate-grown cultures which retain the ability to grow on one of the hydrocarbons, toluene, but show only marginal growth on $m$-xylene and none on $m$-toluate $\left(\mathrm{Mxy}^{-} \mathrm{Tln}^{+} \mathrm{Mtol}^{-}\right)$, which we call the $\mathrm{B} 5$ mutants. In addition, reversion of both B3 and B5 mutants to growth on $m$-toluate is accompanied by a tandem amplification of a $23-28 \mathrm{kbp}$ region of plasmid DNA.

\section{METHODS}

Bacterial strains. A list of strains is presented in Table 1. Plate cultures were maintained on minimal salts agar containing $5 \mathrm{mM}$ - $m$-toluate, except for the B3 and B5 mutants, which were maintained on nutrient agar. To test for growth, toluene and $m$-xylene were presented as vapour to patches of clones made on minimal agar plates; all other substrates were incorporated into the agar at 5 or $10 \mathrm{~mm}$. Batch cultures for enzyme assays were prepared as described by Pickup \& Williams (1982).

Benzoate and $m$-toluate selection. Cells were grown on liquid benzoate minimal medium according to Pickup et al. (1983). For $m$-toluate selection, plates containing $5 \mathrm{~mm}$ - $m$-toluate as single carbon source were patched with single colonies of B3 and B5 mutants of $P$. putida MT15 and incubated for at least 3 weeks at $30^{\circ} \mathrm{C}$. Slowly growing single colonies were purified and maintained on $m$-toluate minimal plates. 


\section{Table 1. Bacterial strains}

\begin{tabular}{|c|c|c|c|}
\hline Strain & Phenotype* & Plasmid & Method of formation \\
\hline Pseudomonas putida MT15 & $\mathrm{Mtol}^{+} \mathrm{Mxy}^{+} \mathrm{Tln}^{+}$ & pWW15 & Wild-type strain \\
\hline MT15-100 & $\mathrm{Mtol}^{-} \mathrm{Mxy}^{-} \mathrm{Tln}^{-}$ & - & Benzoate selection of MT15 (B1) \\
\hline MT15-300 & $\mathrm{Mtol}^{-} \mathrm{Mxy}^{+} \mathrm{Tln}^{+}$ & pWW15-300 & Benzoate selection of MT15 (B3) \\
\hline MT15-500 & $\mathrm{Mtol}^{-} \mathrm{Mxy}^{-} \mathrm{Tln}^{+}$ & pWW15-500 & Benzoate selection of MT15 (B5) \\
\hline MT15-510 & $\mathrm{Mtol}^{-} \mathrm{Mxy}^{-} \mathrm{Tln}^{+}$ & $\mathrm{pWW} 15-510$ & Benzoate selection of MT15 (B5) \\
\hline MT15-450 & $\mathrm{Mtol}^{+} \mathrm{Mxy}^{+} \mathrm{Tln}^{+}$ & pWW15-450 & $m$-Toluate selection of MT15-300 (B3r) \\
\hline MT15-341 & $\mathrm{Mtol}^{+} \mathrm{Mxy}^{+} \mathrm{Tln}^{+}$ & pWW15-341 & $m$-Toluate selection of MT15-300 (B3r) \\
\hline MT15-342 & $\mathrm{Mtol}^{+} \mathrm{Mxy}^{+} \mathrm{Tln}^{+}$ & pWW 15-342 & $m$-Toluate selection of MT15-300 (B3r) \\
\hline MT15-750 & $\mathrm{Mtol}^{+} \mathrm{Mxy}^{+} \mathrm{Tln}^{+}$ & pWW 15-750 & $m$-Toluate selection of MT15-500 (B5r) \\
\hline MT15-751 & $\mathrm{Mtol}^{+} \mathrm{Mxy}^{+} \mathrm{Tln}^{+}$ & pWW15-751 & $m$-Toluate selection of MT15-500 (B5r) \\
\hline MT15-760 & $\mathrm{Mtol}^{+} \mathrm{Mxy}^{+} \mathrm{Tln}^{+}$ & pWW $15-760$ & $m$-Toluate selection of MT15-510 (B5r) \\
\hline
\end{tabular}

${ }^{*} \mathrm{Mtol}^{+}, \mathrm{Mxy}^{+}$and $\mathrm{Tln}^{+}$denote the ability to grow on $m$-toluate, $m$-xylene and toluene, respectively, as sole source of carbon and energy.

Preparation of cell extracts and enzyme assays. Cells were grown in aerated batch culture in $10 \mathrm{~mm}$-acetate minimal medium overnight. For induction by $m$-xylene and toluene, the inducing substrate was supplied throughout growth as vapour in the air supply. When $m$-toluate was used as inducer, it was added at $5 \mathrm{~mm}$ to overnight acetate-grown cultures and incubated with aeration for a further $4-6 \mathrm{~h}$; this minimized the accumulation of black oxidation products of 3-methyl catechol which occurred with B3 and B5 mutants and which ultimately would have killed the cells. Crude extracts of cells for enzyme assay were prepared and the pathway enzyme assays performed according to published procedures (Worsey \& Williams, 1977; Pickup \& Williams, 1982). $\mathrm{C} 12 \mathrm{O}$ was assayed after treatment of extracts with $\mathrm{H}_{2} \mathrm{O}_{2}$ and MLE measured according to Murray \& Williams (1974).

Plasmid isolation and digestion. Plasmid DNA was isolated and digested and the fragments subjected to agarose gel electrophoresis according to Wheatcroft \& Williams (1981). Fragments were sized by comparison with digests of $\mathrm{pWW}$.

Transfer of DNA to nitrocellulose filters and DNA-DNA hybridization. DNA restriction fragments separated by agarose gel electrophoresis were transferred to Biodyne transfer membranes (Pall Ultrafine Filtration Corp., Glen Cove, Ny, USA) by the method of Southern (1975). Cloned plasmid DNA was ${ }^{32} \mathrm{P}$-labelled by nick translation essentially as described by Rigby et al. (1977) using [ $\left.{ }^{32} \mathrm{P}\right] \mathrm{dGTP}$ as labelled precursor. Hybridization conditions were taken from Cheung et al. (1980) using $50 \%(\mathrm{v} / \mathrm{v})$ formamide and incubating in plastic bags at $37^{\circ} \mathrm{C}$ overnight.

\section{RESULTS}

\section{Growth of strain MT15 on benzoate minimal medium}

Growth on benzoate minimal medium is a very strong selection against MT15 wild-type (Williams \& Worsey, 1976); in a number of experiments $100 \%$ of the cells examined after 15 to 20 generations of growth were unable to grow on $m$-toluate. On careful testing of these mutants, they were found to fall into three classes. In addition to B1 mutants $\left(\mathrm{Mxy}^{-} \mathrm{Tln}^{-} \mathrm{Mtol}^{-} \mathrm{Ben}^{+}\right)$ and $\mathrm{B} 3$ mutants $\left(\mathrm{Mxy}^{+} \mathrm{Tln}^{+} \mathrm{Mtol}^{-} \mathrm{Ben}^{+}\right)$, both originally described by Williams \& Worsey (1976), we also found a novel class of segregant, distinct from the B1 and B3 mutants, which grew well on toluene, but minimally on $m$-xylene and not at all on $m$-toluate $\left(\mathrm{Mxy}^{-} \mathrm{Tln}^{+} \mathrm{Mtol}^{-}\right.$ $\mathrm{Ben}^{+}$), which we have called the B5 mutants. The relative frequency of occurrence of these three phenotypic variants fluctuates widely from experiment to experiment, suggesting that the mutational events leading to their formation occur randomly and spontaneously in the population of cells growing on benzoate.

Four mutant strains were retained for further study, MT15-100 (B1), MT15-300 (B3) and two independently isolated B5 mutants, MT15-500 and MT15-510 (Table 1).

\section{Biochemical analysis of mutants}

Assay of the early enzymes of the TOL pathway in MT15-100 (Table 2) demonstrated that it had lost all detectable $\mathrm{C} 23 \mathrm{O}, \mathrm{HMSH}$ and HMSD activities, even under inducing conditions, and only retained very low BADH and BZDH activities: this pattern is characteristic of mutants 
which have either lost the complete plasmid or deleted all the catabolic genes (Worsey \& Williams, 1975), and the low BADH and BZDH activities can be attributed to other enzymes present in the cell which show some cross specificity.

The B3 strain MT15-300 showed an identical induction pattern to the B3 mutants of MT20 (Worsey \& Williams, 1977; Pickup \& Williams, 1982) and of MT14 (Pickup et al., 1983). Whereas growth in the presence of $m$-xylene and toluene resulted in induction of all the TOL pathway enzymes assayed, although at a lower level than in wild-type MT15, growth in the presence of $m$-toluate caused no higher activities than in uninduced cells. This is consistent with the regulatory model proposed for MT20 if there has been the deletion of a regulatory gene, the product of which mediates induction by $m$-toluate. We do not think there is any great significance in the very low activities of C23O in m-toluate-induced MT15-500 compared with acetate-grown cells. The difference may result from a greater susceptibility of $\mathrm{C} 23 \mathrm{O}$ to the toxic black oxidation products which accumulate in $m$-toluate-induced cultures of these mutants.

The B5 mutant, MT15-500, differed from MT15-300 in the effect of induction after growth in the presence of $m$-xylene and toluene. Whereas the upper pathway enzymes, BADH and BZDH, and the lower pathway enzyme, C23O, were induced, the expression of HMSH and HMSD was only at uninduced levels. During growth of strain MT15-500 in liquid medium containing $m$ xylene, the accumulation of 2-hydroxy-6-oxohepta-2,4-dienoate (the ring-cleavage product of $\mathrm{C} 23 \mathrm{O}$ during metabolism of $m$-xylene) was clearly visible, supporting the enzymic evidence that HMSH and HMSD were not expressed.

The ability of MT15-500 to grow on toluene must be explained by its metabolism via the chromosomally encoded ortho pathway. This is apparent from the activities of the ortho pathway enzymes $\mathrm{C12O}$ and MLE in cells of MT15-500 grown on toluene compared with those grown on acetate (Table 2). Admittedly, the activities of these enzymes were not as high as in benzoategrown MT15-100. However, this probably reflects the fact that there is no C23O activity in MT15-100, whereas in MT15-500 some of the toluene is diverted by C23O to 2-hydroxymuconic semialdehyde, as is apparent from the yellow colour in the culture medium. Presumably the activities of $\mathrm{C} 12 \mathrm{O}$ and MLE are sufficient to ensure that the benzoate and catechol accumulating from the metabolism of toluene by the plasmid-encoded enzymes of the top of the pathway can be further degraded to central metabolites by the chromosomally coded ortho pathway enzymes. The corresponding methyl-substituted products from $m$-xylene cannot be thus metabolized because of the stringent specificity of the ortho pathway for unsubstituted substrates only and therefore $m$-xylene is not a growth substrate for the B5 mutants. The induction by $m$-toluate in MT15-500 is indistinguishable from that in MT15-300.

\section{Plasmid analysis of mutants}

MT15 contains a single large plasmid. Careful analysis by methods previously described (Pickup \& Williams, 1982) of agarose gels of digests of the plasmid, pWW15, with five restriction enzymes, three of which are shown in Fig. 2, shows that it contains about $250 \mathrm{kbp}$. The digests of pWW15 with all five enzymes showed a remarkable degree of similarity with the corresponding digests of the two plasmids, $\mathrm{pWW} 14$ and $\mathrm{pWW} 20$, from the other strains which segregate similar mutants. Although both pWW14 and pWW20 are some $40 \mathrm{kbp}$ larger than pWW15, the similarities in their digests suggest that they share a degree of homology of probably $>80 \%$.

Comparison of the plasmid DNA in the various segregants of MT15 resulting from benzoate selection shows the following. (i) The B1 mutant MT15-100 contains no plasmid DNA. (ii) The plasmids in both B3 and B5 mutants have undergone similar but distinguishable deletions of about $90 \mathrm{kbp}$ (Fig. 2). These deletions appear to be of a single continuous length of DNA, since in the digestions by a number of different restriction enzymes, only a single novel fragment, presumably containing the termini of the deletion, was detected (Fig. 2). (iii) The deletions causing the B3 and B5 mutations differ by $<1 \mathrm{kbp}$ and only the EcoRI, BamHI and KpnI digests show any discernible difference between them (Fig. 2). (iv) The plasmids in the two B5 mutants could be distinguished by only $X h o I$ digestion and the difference in size must be less than $0.7 \mathrm{kbp}$. 


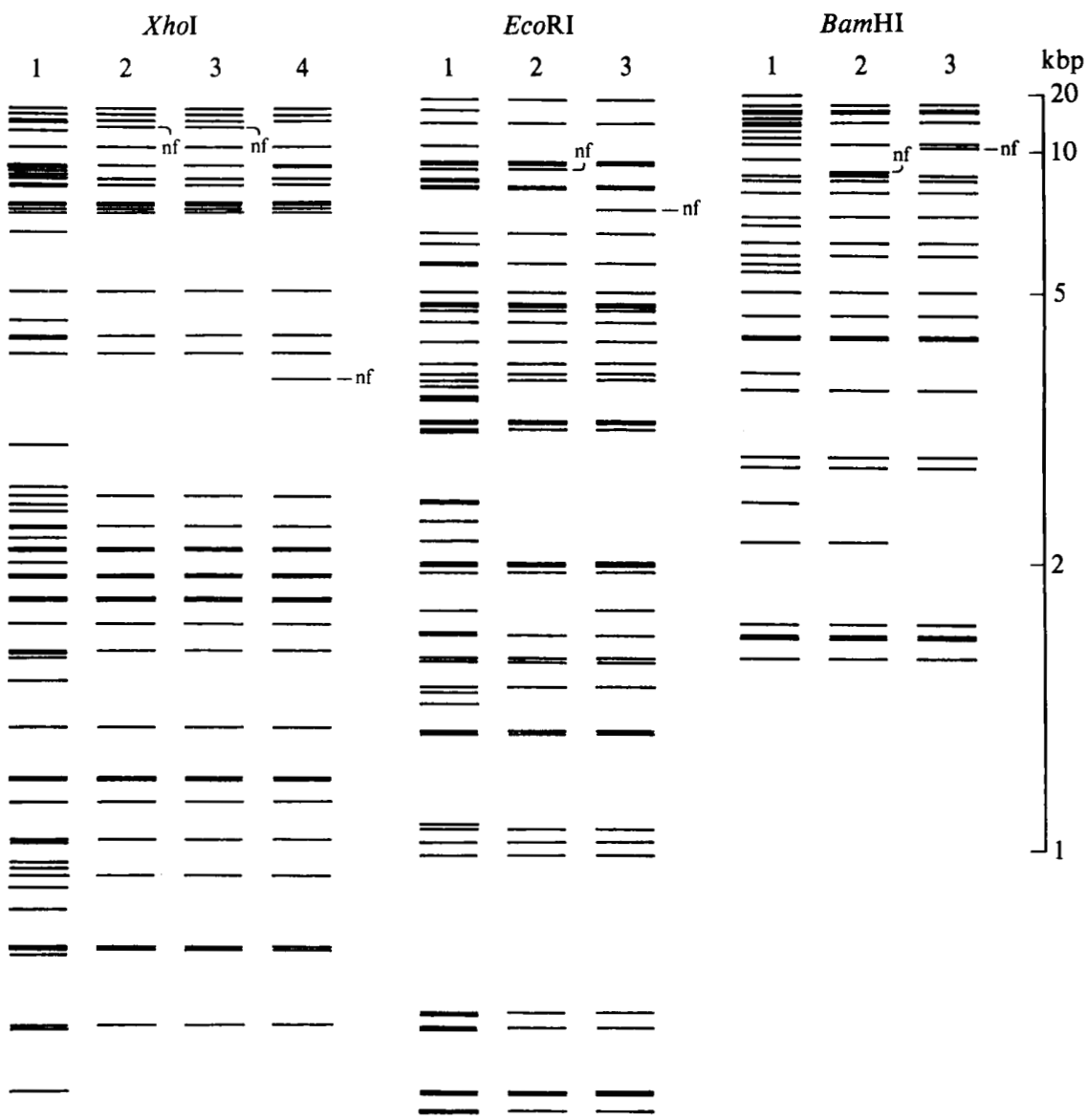

Fig. 2. Diagrammatic representation of the $X h o \mathrm{I}, E c o \mathrm{RI}$ and $B a m \mathrm{HI}$ digests of pWW 15 and its deleted derivatives. Double bands are shown as thick lines. Novel fragments generated by the deletion event are indicated nf. Track 1, pWW15; track 2, pWW15-300; track 3, pWW15-500; track 4, pWW15-510.

\section{Reversion of B3 and B5 mutants on m-toluate}

When B3 or B5 mutants of MT15 were plated onto $m$-toluate minimal agar plates, single colonies of $\mathrm{Mtol}^{+}$revertants appeared at a frequency of about $10^{-6}$. These revertant strains grew more slowly on $m$-toluate than did wild-type MT15. In liquid medium, the revertants took 4-6 d to reach a turbidity achieved by MT15 in 1-2 d; at the same time, substantial quantities of 3methylcatechol (B3 and B5 revertants) and 2-hydroxy-6-oxohepta-2,4-dienoate, the ringcleavage product of 3-methylcatechol (B5 revertants only), were accumulated in the media.

The $\mathrm{Mtol}^{+}$phenotype of the revertants was extremely unstable, and was rapidly lost after subculture in nutrient broth for several cycles. Examinations of $\mathrm{Mtol}^{-}$strains (about $70 \%$ of the population) after 30 generations showed that the B3 revertant, MT15-450, gave rise to segregants with either the original B3 phenotype or the B1 phenotype, indicative of total plasmid loss; in a similar experiment the B5 revertant, MT15-750, segregated either B5 or B1 mutants.

A number of revertants were retained (Table 1), but MT15-450 and MT15-750 were subjected to a more detailed analysis.

\section{Enzyme analysis of revertants}

A comparison of the results of enzyme assays of cell extracts from the two revertants with their corresponding parent strains is shown in Table 2. The most important features of the results can be summarized as follows. (i) After growth on toluene or $m$-xylene strain MT15-450 showed 
Table 2. Activities of plasmid-coded enzymes in cell extracts of derivatives of Pseudomonas putida MT15

Enzyme activities are expressed as milliunits of activity per mg protein.

\begin{tabular}{|c|c|c|c|c|c|c|c|c|}
\hline Strain & Inducer & BADH & BZDH & $\mathrm{C} 23 \mathrm{O}$ & HMSH & HMSD & $\mathrm{C} 12 \mathrm{O}$ & MLE \\
\hline MT15 & $\begin{array}{l}m \text {-Xylene } \\
\text { Toluene } \\
m \text {-Toluate } \\
\text { None }\end{array}$ & $\begin{array}{r}1340 \\
1270 \\
80 \\
30\end{array}$ & $\begin{array}{r}650 \\
390 \\
50 \\
20\end{array}$ & $\begin{array}{r}5700 \\
2900 \\
3700 \\
130\end{array}$ & $\begin{array}{r}370 \\
140 \\
90 \\
8\end{array}$ & $\begin{array}{r}130 \\
60 \\
60 \\
2\end{array}$ & $\begin{array}{l}\text { ND } \\
\text { ND } \\
\text { ND } \\
\text { ND }\end{array}$ & $\begin{array}{l}\text { ND } \\
\text { ND } \\
\text { ND } \\
\text { ND }\end{array}$ \\
\hline $\begin{array}{l}\text { MT15-100 } \\
\text { (B1) }\end{array}$ & $\begin{array}{l}m \text {-Xylene } \\
\text { Toluene } \\
m \text {-Toluate } \\
\text { Benzoate } \\
\text { None }\end{array}$ & $\begin{array}{r}2 \\
3 \\
2 \\
\text { ND } \\
4\end{array}$ & $\begin{array}{r}4 \\
4 \\
2 \\
\text { ND } \\
8\end{array}$ & $\begin{array}{l}<1 \\
<1 \\
<1 \\
<1 \\
<1\end{array}$ & $\begin{array}{l}<1 \\
<1 \\
<1 \\
<1 \\
<1\end{array}$ & $\begin{array}{l}<1 \\
<1 \\
<1 \\
<1 \\
<1\end{array}$ & $\begin{array}{c}\text { ND } \\
\text { ND } \\
\text { ND } \\
43\left(25^{*}\right) \\
5^{*}\end{array}$ & $\begin{array}{c}\text { ND } \\
\text { ND } \\
\text { ND } \\
84 \\
<1\end{array}$ \\
\hline $\begin{array}{l}\text { MT15-300 } \\
\text { (B3) }\end{array}$ & $\begin{array}{l}m \text {-Xylene } \\
\text { Toluene } \\
m \text {-Toluate } \\
\text { None }\end{array}$ & $\begin{array}{r}1500 \\
480 \\
40 \\
50\end{array}$ & $\begin{array}{r}350 \\
160 \\
20 \\
30\end{array}$ & $\begin{array}{r}3500 \\
810 \\
50 \\
140\end{array}$ & $\begin{array}{r}100 \\
60 \\
<1 \\
2\end{array}$ & $\begin{array}{r}20 \\
8 \\
<1 \\
<1\end{array}$ & $\begin{array}{l}\text { ND } \\
\text { ND } \\
\text { ND } \\
\text { ND }\end{array}$ & $\begin{array}{l}\text { ND } \\
\text { ND } \\
\text { ND } \\
\text { ND }\end{array}$ \\
\hline $\begin{array}{l}\text { MT15-500 } \\
\text { (B5) }\end{array}$ & $\begin{array}{l}m \text {-Xylene } \\
\text { Toluene } \\
m \text {-Toluate } \\
\text { None }\end{array}$ & $\begin{array}{r}1060 \\
580 \\
20 \\
70\end{array}$ & $\begin{array}{r}630 \\
350 \\
10 \\
40\end{array}$ & $\begin{array}{r}1900 \\
1360 \\
4 \\
150\end{array}$ & $\begin{array}{r}4 \\
3 \\
<1 \\
<1\end{array}$ & $\begin{array}{r}1 \\
1 \\
<1 \\
<1\end{array}$ & $\begin{array}{c}\text { ND } \\
18^{*} \\
\text { ND } \\
5^{*}\end{array}$ & $\begin{array}{r}\text { ND } \\
25 \\
\text { ND } \\
<1\end{array}$ \\
\hline $\begin{array}{c}\text { MT15-450 } \\
\text { (B3r) }\end{array}$ & $\begin{array}{l}m \text {-Xylene } \\
\text { Toluene } \\
m \text {-Toluate } \\
\text { None }\end{array}$ & $\begin{array}{r}1280 \\
460 \\
140 \\
80\end{array}$ & $\begin{array}{r}460 \\
130 \\
90 \\
50\end{array}$ & $\begin{array}{l}5500 \\
1030 \\
1060 \\
1330\end{array}$ & $\begin{array}{r}550 \\
140 \\
40 \\
20\end{array}$ & $\begin{array}{r}60 \\
70 \\
4 \\
2\end{array}$ & $\begin{array}{l}\text { ND } \\
\text { ND } \\
\text { ND } \\
\text { ND }\end{array}$ & $\begin{array}{l}\text { ND } \\
\text { ND } \\
\text { ND } \\
\text { ND }\end{array}$ \\
\hline $\begin{array}{c}\text { MT15-750 } \\
\text { (B5r) }\end{array}$ & $\begin{array}{l}m \text {-Xylene } \\
\text { Toluene } \\
m \text {-Toluate } \\
\text { None }\end{array}$ & $\begin{array}{r}1930 \\
870 \\
300 \\
220\end{array}$ & $\begin{array}{r}1060 \\
380 \\
130 \\
110\end{array}$ & $\begin{array}{l}5600 \\
3100 \\
3650 \\
3550\end{array}$ & $\begin{array}{r}210 \\
60 \\
20 \\
10\end{array}$ & $\begin{array}{r}60 \\
20 \\
4 \\
2\end{array}$ & $\begin{array}{l}\text { ND } \\
\text { ND } \\
\text { ND } \\
\text { ND }\end{array}$ & $\begin{array}{l}\text { ND } \\
\text { ND } \\
\text { ND } \\
\text { ND }\end{array}$ \\
\hline
\end{tabular}

ND, Not determined.

* Extract was $\mathrm{H}_{2} \mathrm{O}_{2}$-treated.

almost normal activities of all the enzymes assayed compared with its parent strain MT15-300; in strain MT15-750 there was a significant increase in the expression of the lower pathway enzymes HMSH and HMSD, which were only weakly expressed in toluene- and $m$-xyleneinduced parent strain MT15-500. (ii) There was also an elevated level of expression of C23O, HMSH and HMSD after growth of either revertant in the absence of any inducer. (iii) There was no induction of the three lower pathway enzymes in either revertant by $m$-toluate: the activities were roughly the same as those found in the absence of inducer.

It is probable that the actual specific activities of C23O, HMSH and HMSD in uninduced cells of the revertants are somewhat higher than those presented in Table 2, since there was a detectable loss of the $\mathrm{Mtol}^{+}$phenotype of both strains due to their genetic instability in the absence of selection pressure even during the short period required to grow a sufficient quantity of uninduced cells for enzyme assay. This probably accounts for the lower specific activities of HMSH and HMSD (about 50\%) in uninduced cells of MT15-450 and MT15-750 compared with $m$-toluate-induced cells.

\section{Plasmid analysis of revertants}

Digestion of the plasmid DNA in MT15-450 and MT15-750 with restriction endonucleases showed a number of unique features. (i) A number of fragments, which always included the novel fragment generated by the original B3- or B5-type deletion event, had a heightened intensity in the photograph of the agarose gel (Fig. 3, A). (ii) There was always a unique fragment, absent from the plasmid of the parent B3 or B5 mutant, which also showed an increased fluorescence (Fig. 3, A). (iii) In the strains which had regained the B3 or B5 phenotype after subculturing either MT15-450 or MT15-750 through nutrient broth, all the fragments with 
A

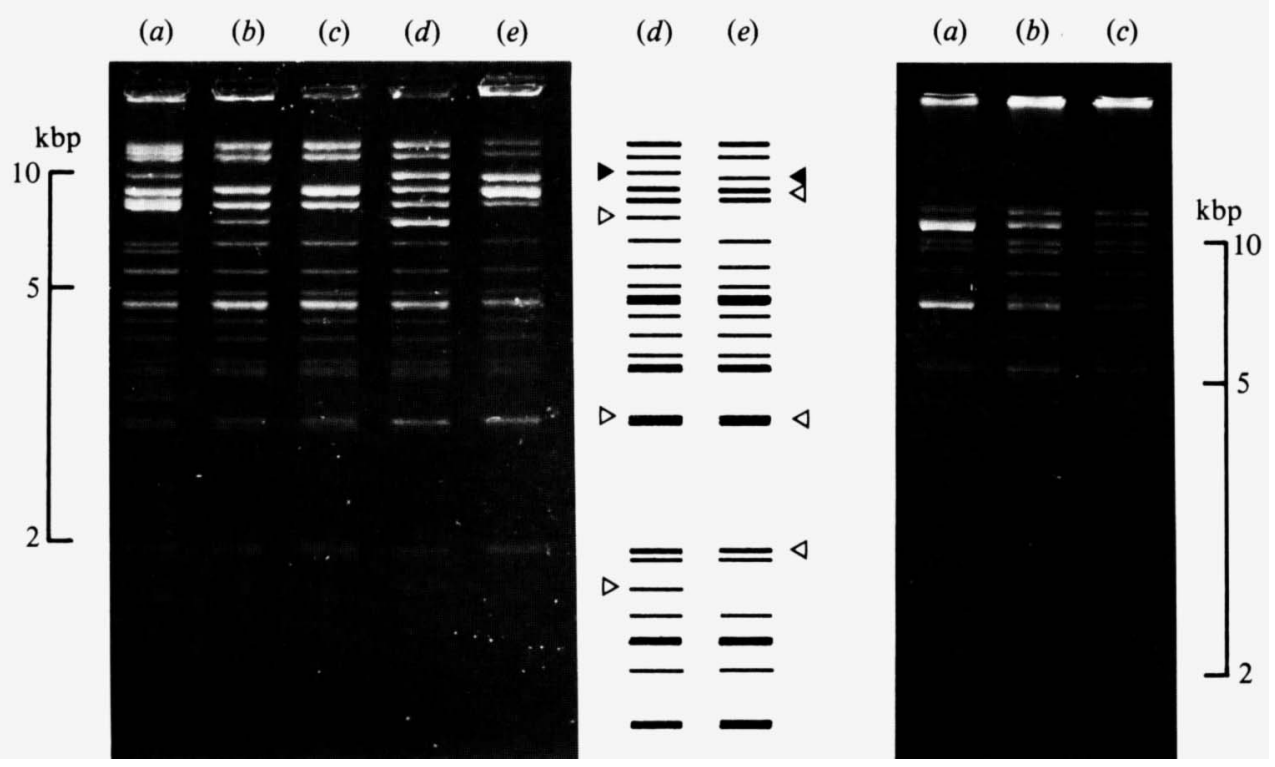

Fig. 3. Agarose gel electrophoresis of restricted plasmid DNA of pWW15 and its deleted and amplified derivatives digested with EcoRI (A) and HindIII (B). A : tracks are (a) pWW 15, (b)pWW15-500, (c) pWW15-300, (d) pWW15-750, (e) pWW15-450; the diagram on the right indicates the corresponding amplified bands more clearly $(D$, novel fragment generated by the amplification; $\rightarrow$, other amplified fragments). B: Visualization of the gradual deamplification under non-selective growth conditions. Tracks are: plasmid DNA isolated from MT15-750 cultured on $m$-toluate (a), after subculturing for about 30 generations in nutrient broth $(b)$ and after 60 generations in nutrient broth $(c)$.

increased intensity had reverted to their original intensity and the unique novel fragment found only in the revertants had disappeared. Furthermore, if plasmid analysis of the total culture during nonselective growth was carried out, the change was seen to occur gradually as the population altered (Fig. 3, B).

These features are consistent with a tandem amplification of part of the plasmid DNA on either side of the termini of the large $90 \mathrm{kbp}$ deletion which caused the original B3 or B5 mutation. The exact extent of the DNA amplified varied from strain to strain. Three independent revertants of MT15-300 (MT15-341, MT15-342 and MT15-450), two of MT15-500 (MT15-750, MT15-751) and one of MT15-510 (MT15-760) showed similar but distinguishable amplified regions ranging in size from $23 \mathrm{kbp}$ (MT15-750) to $28 \mathrm{kbp}$ (MT15-341).

The degree of amplification was estimated to be 4-5 copies by densitometric measurement of the negatives of photographs of various restriction enzyme digestions of MT15-450 and MT15750 plasmid DNA (data not shown).

\section{DNA-DNA hybridization}

To verify that the genes for the upper pathway enzymes BADH and BZDH were not on the amplified DNA, a cloned $7 \mathrm{kbp}$ HindIII fragment of the TOL plasmid pWW 53 carrying the two genes (R. W. Pickup, personal communication) was labelled and used as a probe against digests of pWW15 and the plasmids in the various strains. The results for the BamHI digest are shown in Fig. 4, A. In the BamHI digest, four fragments of pWW15 (data not shown), pWW15-300 and pWW 15-500 showed homology with the probe with sizes 8.8,6.9, 3.4 and $1.8 \mathrm{kbp}$; of these, only the $3.4 \mathrm{kbp}$ fragment (BZ) was amplified and then in only one of the revertant strains (MT15341 ) which had the largest amplified region. In the EcoRI digests, three fragments, of 9, 6.6 and $4.7 \mathrm{kbp}$, hybridized, and in the HindIII digests only two fragments, of 9 and $7.3 \mathrm{kbp}$ (not shown). 

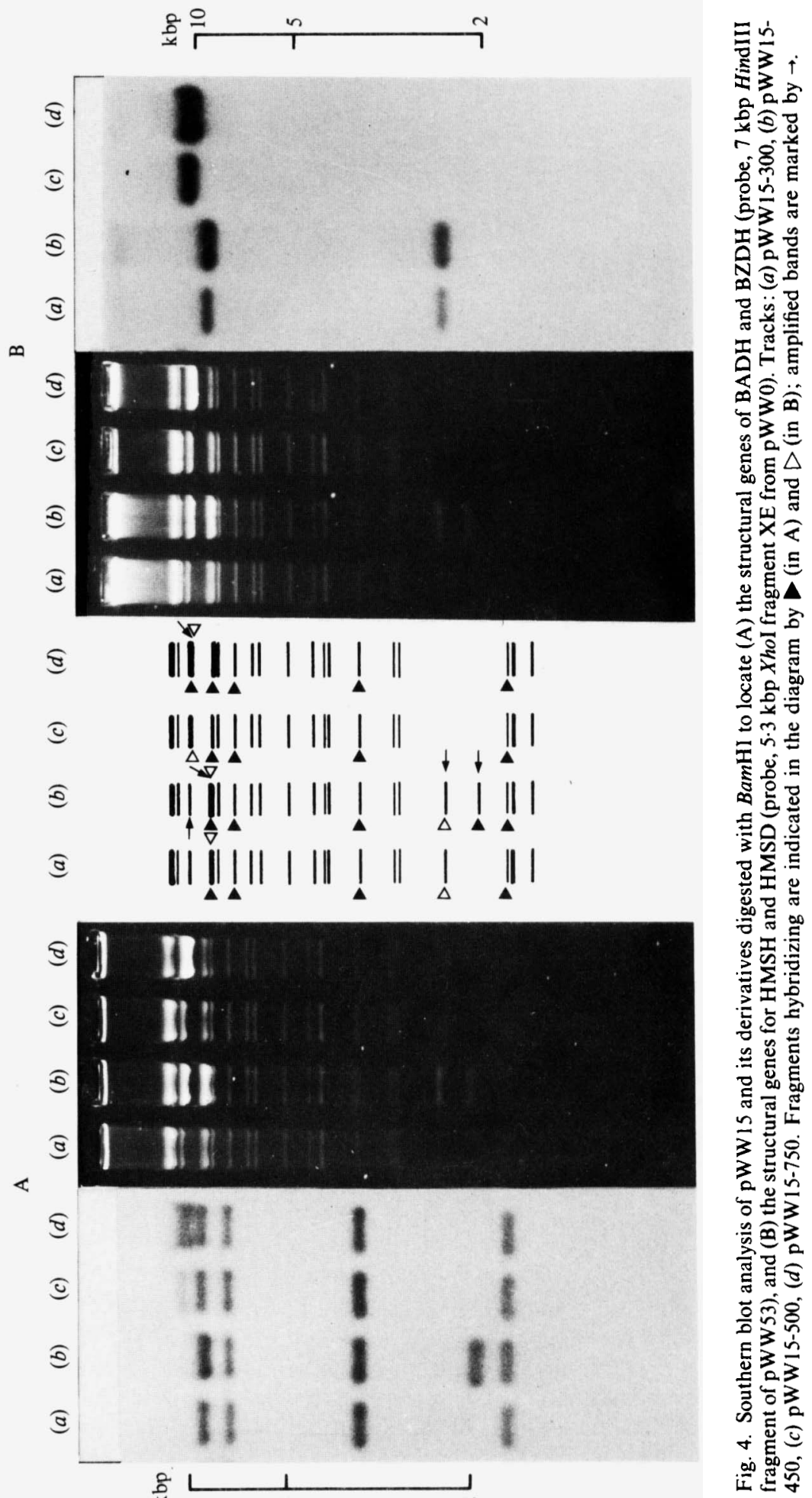
In the digests of the revertant strains the same bands also hybridized, but in addition, in every digest the novel fragment generated by the amplification showed homology with the probe. With the one exception of BZ in MT15-341, this was the only amplified fragment which did hybridize. This suggests that the genes for BADH and BZDH are close to but not part of the amplified region. To detect the lower pathway genes on both amplified and non-amplified pWW 15 DNA, the $5.3 \mathrm{kbp}$ XhoI fragment XE of pWW0 carrying HMSH and HMSD structural genes (Franklin et al., 1981) was labelled and hybridized to the same DNA as the upper pathway probe. In both the amplified and non-amplified plasmid DNA the same BamHI restriction bands show strong homology to XE, a $2.2 \mathrm{kbp}$ fragment and the novel fragment in pWW15-300 and pWW 15-450, and only the novel fragments in pWW15-500 and pWW15-750 (Fig. 4, B), all hybridizing fragments being part of the amplified region.

\section{Comparison with $p W W 14$ and $p W W 20$}

The discovery of the similarity in the restriction digests between pWW15 and the previously studied plasmids pWW14 and pWW20, and the new observation about the formation of the novel B5 mutants, prompted us to re-examine the effect of benzoate selection on MT14 and MT20. In addition to forming B1 and B3 mutants as has been previously described (Williams \& Worsey, 1976) we found that both of these strains formed B5 mutants which had been overlooked in the previous studies. Comparison of the plasmid DNA in the segregants showed that pWW15 and pWW20 appear to delete a virtually identical region in their B3 and B5 mutants, whereas the deletions in pWW14 are consistently about $4 \mathrm{kbp}$ larger. In addition B3 and B5 mutants of both MT14 and MT20 can be reverted to $\mathrm{Mtol}^{+}$phenotype with the concomitantly occurring amplification of about $25 \mathrm{kbp}$ of the DNA on either side of the deletion termini very similar to strain MT15.

\section{DISCUSSION}

Growth on benzoate minimal medium, selecting for segregants of TOL plasmid-containing strains which have lost the ability to metabolize benzoate by the plasmid-coded meta pathway and use the chromosomally coded ortho (or $\beta$-ketoadipate) pathway, has proved a powerful tool in the study of TOL plasmids. Originally it was used because it was believed to be a simple method of curing the plasmids (Williams \& Murray, 1974; Williams \& Worsey, 1976). In this it has proved effective since plasmid-free segregants are found ubiquitously after benzoate selection of virtually every strain containing a TOL plasmid. However, many of the strains also give rise to segregants which have undergone deletions in the plasmid which result either in total loss of the catabolic genes or in a partial loss of some of the genes, resulting in incomplete expression of the full TOL pathway (Bayley et al., 1977; Kunz \& Chapman, 1981; Pickup \& Williams, 1982; Pickup et al., 1983; Williams et al., 1983). The study of these deleted plasmids has led to new insights into their structure and function. The B5 segregants of pWW15 (and pWW14 and pWW20) described for the first time in this paper are phenotypically identical to the segregants typified by strain PpCTl derived from P. putida HSl (Kunz \& Chapman, 1981). In PpCT1 the wild-type plasmid pDK 1 of $120 \mathrm{kbp}$ had undergone a deletion of $60 \mathrm{kbp}$, and had irreversibly lost all expression of the complete lower pathway enzymes from toluate oxidase down: it was assumed that the deletion included their structural genes. Biochemically, however, the B5 mutants differ from PpCT1 since they retain full expression of toluate oxidase and C23O and are only defective in HMSH and HMSD expression. The genes for these enzymes have not been deleted from the plasmid since their expression can be regained when they revert to the pseudo-wild-type phenotype $\mathrm{Mxy}^{+} \mathrm{Tln}^{+} \mathrm{Mtol}^{+}$on $m$-toluate selection. The deletion of plasmid DNA in these mutants must therefore involve the loss of regulatory elements and/or the addition of new regulatory elements by the juxtaposition of the structural genes to regulatory DNA previously distant on the plasmid prior to the deletion. The evidence presented here does not modify our previous hypothesis that the B3 phenotype results from loss of a major positive regulator gene responsible for mediating induction by $m$-toluate. Although we have no definitive evidence to show that there is such a gene in $\mathrm{pWW} 15$, or that the pathway regulation on $\mathrm{pWW} 15$ 
is the same as on pWW0, a gene ( $x y l S)$ with the expected function has been located and cloned from the archetypal TOL plasmid pWW0 (Inouye et al., 1981; Franklin et al., 1983). The evidence from the enzyme assay data is that the same lesion has occurred in the B5 mutants with an additional effect such that the $x y l F$ and $x y l G$ gene products HMSH and HMSD are not expressed. Since the deletions in the B3 and B5 mutants are very similar it seems unlikely that the difference can involve more than one gene. We have no explanation for this difference at present, although there are preliminary indications, not presented here, that one end of the deletion is very close to the structural genes for HMSH and HMSD and may well have an effect on their transcription.

It was further demonstrated that the B3 and the B5 mutants of $P$. putida MT15, which result from a $90 \mathrm{kbp}$ deletion of $\mathrm{pWW} 15$, can revert to growth on $m$-toluate, albeit poorly. In an earlier study with $P$. putida MT20, a strain carrying the very similar plasmid $\mathrm{pWW} 20$, reversion of a B3 segregant was reported, and like the results presented here, the revertant showed a low semiconstitutive level of expression of the lower pathway enzymes (Worsey \& Williams, 1977). However, in the absence of any physical evidence about the plasmid DNA in MT20 and any investigation of the genetic stability of the revertant, it was assumed that the reversion was the result of a point mutation in the regulatory gene which mediates induction by $m$-xylene, changing the structure of its product such that it induced the enzymes for catabolism of $\mathrm{m}$ toluate in the absence of inducer. This was probably an incorrect conclusion since we have now looked at revertants of both B3 and B5 mutants of MT20 and, like the situation in MT15, the reversion is accompanied by DNA amplification.

The explanation as to how the amplification permits growth on $m$-toluate is at present unclear. The simplest and most obvious explanation is that it is a gene dosage effect such as has been described for plasmid-specified antibiotic resistance genes (Perlman \& Rownd, 1975) and also for the chromosomally coded catabolic ribitol dehydrogenase gene of Klebsiella aerogenes (Neuberger \& Hartley, 1981). If this is the case, then it would imply that the genes for enzymes $\mathrm{C} 23 \mathrm{O}$, HMSH and HMSD (and probably other enzymes further down of the pathway not assayed in this study) were located in the amplified region as was demonstrated by hybridization experiments (Fig. 4); examination of the specific activities (Table 2) suggests that the DNA was amplified about 10-fold in MT15-450, compared with the estimate of 4-5-fold from the intensity of the amplified bands on the photographs. An alternative possibility is that the amplification relocates the structural genes for the lower pathway enzymes downstream of a stronger constitutive promoter than is present in the parental B3 or B5 mutants. It is certain from the hybridization results that the upper pathway genes are not involved in the amplified region, and this is supported by the enzyme data which show that the amplification does not affect their expression.

The variable nature of the termini of the amplifications makes it unlikely that it is the presence of two unique DNA sequences analogous to insertion sequences which determines the extent of DNA amplified. It is also worth noting that in the wild-type plasmid pWW15 the two ends of the region which is amplified are separated by about $110 \mathrm{kbp}$, i.e. on virtually opposite sides of the plasmid.

We are at present cloning the DNA from the amplified region to provide a fine structure restriction map and locate the structural genes of the catabolic pathway.

Although MT14, MT15 and MT20 were isolated in separate enrichment cultures and are Pseudomonas strains with quite distinguishable properties (Williams \& Worsey, 1976), their plasmids are obviously closely related in their structure and properties. This is a similar situation to that found for some independently isolated $\mathbf{R}$ plasmids which differ only by the occurrence of various insertions/deletions (Sharp et al., 1973). Even though the three strains were isolated from soils within a few hundred metres' radius of the authors' laboratory, it does imply that plasmid transfer can and does occur in the natural environment and that changes in structure can take place during this process. However, more than that, this paper presents yet another example of the variety of often quite major structural changes which can take place in the DNA of catabolic plasmids when the host strains are subject only to pressures of change of growth substrate (Williams et al., 1983). It reinforces our belief that the occurrence of such structural changes, 
taking place as they do in nonessential DNA and selected for by apparently quite innocuous alterations in available carbon sources, demonstrates strongly the potential importance of plasmids in the evolution of new arrangements of DNA.

We should like to acknowledge the award of a European Science Exchange Programme Fellowship to H.K. by the Deutsche Forschungsgemeinschaft and the Royal Society.

\section{REFERENCES}

Bayley, S. A., Duggleby, C. J., Worsey, M. J., Williams, P. A., Hardy, K. G. \& Broda, P. (1977). Two modes of loss of the TOL function from Pseudomonas putida mt-2. Molecular and General Genetics 154, 203-204.

Cheung, A. K. H., Hoggan, M. D., Hauswirt, W. W. \& BERNS, K. I. (1980). Integration of the adeno-associated virus genome in cellular DNA in latently infected Human Detroit 6 cells. Journal of Virology 33, 739-748.

Duggleby, C. J., Bayley, S. A., Worsey, M. J., Williams, P. A. \& BrodA, P. (1977). Molecular sizes and relationships of TOL plasmids in Pseudomonas. Journal of Bacteriology 130, 1274-1280.

Franklin, F. C. H., Bagdasarian, M., Bagdasarian, M. M. \& Timmis, K. N. (1981). Molecular and functional analysis of the TOL plasmid $\mathrm{pWW} 0$ from Pseudomonas putida and cloning of genes for the entire regulated aromatic ring meta cleavage pathway. Proceedings of the National Academy of Sciences of the United States of America 78, 7458-7462.

Franklin, F. C. H., Lehrbach, P. R., LuRz, R., Rueckert, B., Bagdasarian, M. \& Timmis, K. N. (1983). Localisation and functional analysis of transposon mutations in regulatory genes of the TOL catabolic pathway. Journal of Bacteriology 154, 676685.

Inouye, S., Nakazawa, A. \& Nakazawa, T. (1981). Molecular cloning of gene $x y l S$ of the TOL plasmid: evidence for the positive regulation of $x y l D E F G$ operon by $x y l S$. Journal of Bacteriology 148, 413-418.

Kunz, D. A. \& Chapman, P. J. (1981). Isolation and characterisation of spontaneously occurring TOL plasmid mutants of Pseudomonas putida HSl. Journal of Bacteriology 146, 952-964.

MURRay, K. \& Williams, P. A. (1974). Role of catechol and the methylcatechols as inducers of aromatic metabolism in Pseudomonas putida. Journal of Bacteriology 117, 1153-1157.

Neuberger, M. S. \& Hartley, B. S. (1981). Structure of an experimentally evolved gene duplication encoding ribitol dehydrogenase in a mutant of Klebsiella aerogenes. Journal of General Microbiology 122, 181-191.

Perlman, D. \& Rownd, R. H. (1975). Transition of R factor NR1 in Proteus mirabilis: molecular structure and replication of NR1 deoxyribonucleic acid. Journal of Bacteriology 123, 1013-1034.

Pickup, R. W. \& Williams, P. A. (1982). Spontaneous deletions in the TOL plasmid pWW20 which give rise to the B3 regulatory mutants of Pseudomonas putida MT20. Journal of General Microbiology 128, 1385-1390.
Pickup, R. W., Lewis, R. J. \& Williams, P. A. (1983). Pseudomonas sp. MT14, a soil isolate which contains two large catabolic plasmids, one a TOL plasmid and one coding for phenylacetate catabolism and mercury resistance. Journal of General Microbiology 129, 153-158.

Rigby, P. W., Dieckmann, M., Rhodes, C. \& Berg, P. (1977). Labelling deoxyribonucleic acid to high specific activity in vitro by nick-translation with DNA polymerase I. Journal of Molecular Biology 113, 237-245.

Sharp, P. A., Cohen, S. N. \& Davidson, N. (1973). Electron microscope heteroduplex studies of sequence relations among plasmids of Escherichia coli. II. Structure of drug resistance (R) factors and F factors. Journal of Molecular Biology 75, 235-255.

SOUTHERN, E. M. (1975). Detection of specific sequences among DNA fragments separated by gel electrophoresis. Journal of Molecular Biology 98, 505-518.

Wheatcroft, R. J. \& Williams, P. A. (1981). Rapid methods for the study of both stable and unstable plasmids in Pseudomonas. Journal of General Microbiology 124, 433-437.

Williams, P. A. \& Murray, K. (1974). Metabolism of benzoate and the methylbenzoates by Pseudomonas putida (arvilla) mt-2: evidence for the existence of a TOL plasmid. Journal of Bacteriology 120, 416-423.

WilliaMs, P. A. \& WorSEY, M. J. (1976). Ubiquity of plasmids in coding for toluene and xylene metabolism in soil bacteria: evidence for the existence of new TOL plasmids. Journal of Bacteriology 125 , 818-828.

Williams, P. A., Cane, P. A., Jeenes, D. J. \& Pickup, R. W. (1983). Correlation between spontaneous phenotypic changes in Pseudomonas strains with changes in the structure of catabolic plasmids: experiences with TOL plasmids. In Basic Biology of New Developments in Biotechnology, pp. 519-552. Edited by A. Hollaender, A. I. Laskin \& P. Rogers. New York \& London: Plenum Press.

WORSEY, M. J. \& Williams, P. A. (1975). Metabolism of toluene and xylenes by Pseudomonas putida (arvilla) $\mathrm{mt}-2$ : evidence for a new function of the TOL plasmid. Journal of Bacteriology 124, 7-13.

WORSEY, M. J. \& WilliaMs, P. A. (1977). Characterisation of a spontaneously occurring mutant of the TOL 20 plasmid in Pseudomonas putida MT20: possible regulatory implications. Journal of Bacteriology 130, 1149-1158. 